\title{
Hematobiochemical and Antioxidant Evaluation of Aloe vera Whole Leaf Extract on Fluoride Induced Toxicity in Wistar Albino Rats
}

\author{
Navathej A, Sujatha $\mathrm{K}^{*}$, Srilatha Ch and Adhilakshmamma K \\ Department of Veterinary Pathology, College of Veterinary Science, Sri Venkateswara Veterinary University, Tirupati, India
}

Received: February 09, 2016; Accepted: April 01, 2016; Published: April 16, 2016

*Corresponding author: K. Sujatha, Department of Veterinary Pathology, College of Veterinary Science, Tirupati - 517502, Andhra Pradesh, India, E-mail: karamalasujatha@gmail.com

\begin{abstract}
Aloe vera whole leaf extract has a powerful antioxidant system by superoxide anion radicals scavenging, metal ion chelation, reducing power, hydroxyl radicals scavenging and total antioxidant activity in linoleic acid emulsion system. Aloe vera has been used worldwide both for pharmaceutical, food, and cosmetic industries due to the plethora of biological activities of some of its metabolites. Aloe vera also possesses anti-inflammatory, antitumor, anti-arthritic, antibacterial, antiulcer, hypoglycemic effects. Sub chronic administration of fluoride results in hematobiochemical alterations and Aloe vera amelioration in rats. Male Wistar albino rats that were randomly divided into four groups $(\mathrm{n}=18)$. Sodium Fluoride was orally administered at $18 \mathrm{mg}$ $\mathrm{NaF} / \mathrm{kg}$ body weight to groups II and Aloe Vera at $200 \mathrm{mg} / \mathrm{kg}$ body wt. in distilled water was given along with Sodium Fluoride to group IV for 45 days to study its ameliorative effects. Group I and III were act as controls and treated with distilled water and Aloe vera respectively. The present data revealed reductions was recorded in the Hemoglobin (Hb) and Packed Cell Volume (PCV) and mean lymphocyte values whereas significant increase was noticed in TLC values and mean neutrophil count in NaF fed group. Serum total protein and calcium values were decreased significantly and serum creatinine and alkaline phosphatase levels were increased significantly in $\mathrm{NaF}$ treated rats. Oxidative damage indicators like SOD, Catalase and GPx levels were decreased in liver and kidney of all the $\mathrm{NaF}$ treated rats. In aloe ameliorated rats (Group IV), significant improvement was observed haemotologically biochemically and antioxidant status when compared to the NaF treated group (Group II) due to direct or indirect hematoaugmenting properties, immunostimulatory effect and antioxidant properties of Aloe vera.
\end{abstract}

Keywords: Sodium fluoride toxicity; Hematology; Biochemical alterations; Antioxidant status; Aloe vera amelioration; Wistar rats

\section{Introduction}

Fluorosis is a major public health problem resulting from long-term consumption of water with high fluoride levels. In India, the states of Andhra Pradesh, Bihar, Chhattisgarh, Haryana, Karnataka, Madhya Pradesh, Maharashtra, Orissa, Punjab, Rajasthan, Tamil Nadu, Uttar Pradesh and West Bengal are affected by fluoride contamination in water. This involves about 9000 villages affecting 30 million people [1]. Sources of fluoride toxicity includes feed supplements and mineral mixtures with high fluoride containing rock phosphates, drinking water in fluoride rich soils (deep wells), consumption of forages by livestock grown in fluoride rich soils (stems and leaves accumulate fluoride), wire and cable insulations, pipe linings, rocket propellants, rodenticides, refrigerants, aerosol propellants, polymers for plastics, in the separation of uranium isotopes, and in the aluminum, beryllium, antimony, superphosphate fertilizer, electronic ceramics, fluorospar, the brick industries, industrial effluents, fumes from aluminium smelting factories, glass etching industries, acaricides, etc.,

Chronic fluoride poisoning is known to cause a variety of pathological changes in soft tissues. Structural and functional changes in muscle, liver, kidney, gastrointestinal tract, several reproductive and endocrine organs. Since, drinking water is the major source of excess fluoride, different techniques were developed for fluoride removal from water. However, most of them are unfit for clinical use because of chronic nature of the problem and associated side effects after their prolonged use. Therefore, nutritional intervention with antioxidant-rich substances is the ultimate goal as antidotes for combating with the health complaints arising from Fluorosis [2,3]. The toxic metal ions have been implicated in the generation of Reactive Oxygen Species (ROS) and Nitric Oxide (NO) and plant flavonoids could protect against oxidative damage.

In recent years, a considerable emphasis has been focused on the importance of the naturally available botanicals that can be consumed in an individual's everyday diet because of their antioxidant and anti-inflammatory properties [4]. Flavonoids may exert their beneficial effects either through their ability to lower oxidative stress and inflammation or directly by altering the signaling involved in neuronal communication, calcium buffering ability, neuroprotective stress shock proteins, plasticity, and stress signaling pathways [5].

Aloe vera has been used worldwide both for pharmaceutical, food, and cosmetic industries due to the plethora of biological activities of some of its metabolites. Aloe vera possesses 
anti-inflammatory, antioxidant; antitumor, anti-arthritic, antibacterial, antiulcer, hypoglycemic effects [6]. Aloe vera has a powerful antioxidant system by superoxide anion radicals scavenging, metal ion chelation, reducing power, hydroxyl radicals scavenging and total antioxidant activity in linoleic acid emulsion system.

The experiment was carried out to study hematobiochemical and antioxidant evaluation of Aloe vera in sodium fluoride induced toxicity in male wistar albino rats with the following objectives.

1. To study the hematological and biochemical changes associated with sodium fluoride toxicity.

2. To study the oxidative damage associated with sodium fluoride toxicity.

3. To study the ameliorating effect of herbal product i.e. Aloe vera whole leaf extract in sodium fluoride induced toxicity.

\section{Materials and Methods}

\section{Experimental animals}

Male Wistar albino rats that were randomly divided into four groups $(n=18)$. During the experiment, the animals were kept in plastic cages in 12 light and dark cycles. The rats were randomized into four groups based on their body weights, so that the mean body weight of each group was comparable. Sodium Fluoride was orally administered at $18 \mathrm{mg} \mathrm{NaF} / \mathrm{kg}$ body weight to groups II and Aloe Vera at $200 \mathrm{mg} / \mathrm{kg}$ body wt. in distilled water was given along with Sodium Fluoride to group IV for 6 weeks to study ameliorative effects. Group I and III were treated with distilled water and Aloe vera respectively. Six rats from each group were sacrificed at fortnight interval. The experiment was conducted for 6 weeks with protocols approved by the institutional animal ethical committee.

\section{Hematology}

Blood was collected in 10\% EDTA solution from all the groups at each sacrifice was used for the estimation of Total Leukocytes Count (TLC), Packed Cell Volume (PCV) by Microhematocrit method [7], Hemoglobin (Hb) by Sahli's method [8]. The blood smears were directly prepared and stained by Leishman's stain for Differential Leukocytes Count (DLC) by battlement method [5] and absolute counts were also calculated.

\section{Biochemical profiles}

Blood was collected from all groups at each sacrifice directly in to the sterile test tube and allowed to clot. The serum was collected and stored at $4^{\circ} \mathrm{C}$ until use and was used for the estimation of total serum proteins, calcium and alkaline phosphatase [ROBONIK (India) PVT Ltd] and creatinine [MEDSOURCE OZONE BIOMEDICALS Pvt. Ltd.].

\section{Antioxidant status}

At the end each sacrifice the liver and kidney were dissected and stored at $-20^{\circ} \mathrm{C}$ until use. Tissue pieces of each organ were homogenized in $0.05 \mathrm{M}$ ice cold phosphate buffer ( $\mathrm{pH}$ 7.4). The homogenate was mixed with $10 \%$ trichloroacetic acid in the ratio of $1: 1$, centrifuged at $15,000 \mathrm{rpm}$ for $60 \mathrm{~min}$ at $4^{\circ} \mathrm{C}$ and the supernatant obtained was used for estimation of super oxide dismutase [9], catalase [10] and glutathione peroxidise [11] in liver and kidney of all animals in all groups.

\section{Statistical analysis}

The data of both control and experimental groups were statistically analysed (one way ANOVA [12]) and significance was determined at results.

\section{Results and Discussion}

\section{Hematology}

The Mean and S.E values of Hematological parameters of different experimental groups (I, II, III \& IV) are shown in Table 1. A significant $(P<0.05)$ decrease in $\mathrm{Hb}$ and PCV values was recorded in $\mathrm{NaF}$ treated rats (Group II) when compared to control rats (Group I). There was a significant increase in $\mathrm{Hb}$ and PCV values of amelioration group (Group IV) when compared to $\mathrm{NaF}$ treated group (Group II). There was a significant $(P<$ $0.05)$ increase in TLC and mean neutrophil count values in NaF treated rats (Group II) when compared to the control rats (Group I). No significant decrease was noticed in TLC value of Group IV (aloe vera ameliorated rats) when compared to the Group II (NaF treated rats). Where as a significant $(P<0.05)$ decrease in mean lymphocytes count values in $\mathrm{NaF}$ treated rats (Group II) when compared to the control rats (Group I). Non significant improvement was noticed in mean lymphocytes count values of Group IV (aloe vera ameliorated rats) when compared to the Group II (NaF treated rats).

\section{Biochemical alterations}

The Mean and S.E values of Biochemical parameters and Antioxidant status of different experimental groups (I, II, III \& IV) are shown in Table 2. A significant $(P<0.05)$ decrease in total serum proteins and calcium levels in $\mathrm{NaF}$ treated rats (Group II) when compared to control rats (Group I). Non significant increase was recorded in mean TSP and calcium values of aloe vera ameliorated rats (Group IV) when compared to the NaF treated rats (Group II). There was significant $(P<0.05)$ increase in serum creatinine and serum Alkaline Phosphatase (AKP) levels in $\mathrm{NaF}$ treated rats (Group II) when compared to the control rats (Group I). Non significant decrease was noticed in mean serum creatinine levels and a significant decrease in serum AKP levels of aloe vera ameliorated rats (Group IV) when compared to the $\mathrm{NaF}$ treated rats (Group II).

\section{Antioxidant status}

The Mean and S.E values of Antioxidant status of different experimental groups (I, II, III \& IV) are shown in Table 3 respectively. Catalase, SOD and GPX overall mean values of liver and kidney of $\mathrm{NaF}$ treated rats (Group II) were significantly $(P<0.05)$ reduced when compared to control rats (Group I). Whereas non significant improvement was noticed in catalase and superoxide dismutase overall mean values of ameliorated 


\begin{tabular}{|l|l|l|l|l|}
\hline \multicolumn{5}{|l|}{ Table 1: Mean and Standard Error (SE) values of different hematological parameters in rats of different experimental groups. } \\
\hline Parameters Studied & Group I & Group II & Group III & Group IV \\
\hline Hemoglobin concentration (g\%) & $13.73 \pm 0.15^{\mathrm{a}}$ & $8.80 \pm 1.27^{\mathrm{b}}$ & $14.47 \pm 0.15^{\mathrm{a}}$ & $14.53 \pm 0.18^{\mathrm{a}}$ \\
\hline Packed cell volume (\%) & $43.33 \pm 0.88^{\mathrm{a}}$ & $26.00 \pm 3.21^{\mathrm{b}}$ & $45.00 \pm 0.58^{\mathrm{a}}$ & $42.33 \pm 0.88^{\mathrm{a}}$ \\
\hline Total Leukocytes Count (thousands/ $\mu$ l) & $7.50 \pm 0.18^{\mathrm{b}}$ & $13.73 \pm 1.04^{\mathrm{a}}$ & $7.16 \pm 0.12^{\mathrm{b}}$ & $8.48 \pm 0.15^{\mathrm{b}}$ \\
\hline Neutrophils Count (\%) & $14.67 \pm 0.88^{\mathrm{b}}$ & $29.00 \pm 4.36^{\mathrm{a}}$ & $16.33 \pm 0.88^{\mathrm{b}}$ & $17.67 \pm 0.88^{\mathrm{b}}$ \\
\hline Lymphocytes Count (\%) & $83.00 \pm 1.00^{\mathrm{a}}$ & $68.00 \pm 4.36^{\mathrm{b}}$ & $80.33 \pm 1.20^{\mathrm{a}}$ & $80.33 \pm 0.88^{\mathrm{a}}$ \\
\hline
\end{tabular}

Table 2: Mean and Standard Error (SE) values of different biochemical parameters in rats of different experimental groups.

\begin{tabular}{|c|c|c|c|c|}
\hline Parameters Studied & Group I & Group II & Group III & Group IV \\
\hline Total serum protein (g/dl) & $9.58 \pm 0.43^{a}$ & $7.06 \pm 0.88^{b}$ & $10.54 \pm 0.35^{\mathrm{a}}$ & $9.62 \pm 0.40^{\mathrm{a}}$ \\
\hline Calcium (mg/dl) & $61.82 \pm 1.66^{\mathrm{a}}$ & $29.52 \pm 3.43^{b}$ & $63.59 \pm 3.99^{a}$ & $54.89 \pm 3.73^{\mathrm{a}}$ \\
\hline Creatinine (mg/dl) & $0.27 \pm 0.03^{b}$ & $0.58 \pm 0.14^{\mathrm{a}}$ & $0.27 \pm 0.03^{\mathrm{b}}$ & $0.32 \pm 0.01^{\mathrm{b}}$ \\
\hline Alkaline Phosphatase (IU/lt) & $98.66 \pm 3.07^{c}$ & $179.28 \pm 19.73^{a}$ & $95.91 \pm 5.32^{c}$ & $136.95 \pm 5.55^{b}$ \\
\hline
\end{tabular}

Table 3: Mean and SE values of Catalase, Superoxide Dismutase and glutathione Peroxide activity in liver and kidney of rats of different experimental groups.

\begin{tabular}{|l|l|l|l|l|l|l|}
\hline \multirow{2}{*}{$\begin{array}{l}\text { Experimental } \\
\text { groups }\end{array}$} & \multicolumn{2}{|l|}{$\begin{array}{l}\text { Catalase (nM of } \mathbf{H}_{2} \mathbf{O}_{2} \text { decomposed } \\
\text { /min/mg of protein) }\end{array}$} & \multicolumn{2}{l|}{$\begin{array}{l}\text { Superoxide Dismutase (SOD) (U/ } \\
\text { min/mg of protein) }\end{array}$} & \multicolumn{2}{l|}{$\begin{array}{l}\text { Glutathione Peroxide (GPx) activity (U/ } \\
\text { min/mg of protein) }\end{array}$} \\
\cline { 2 - 7 } & Liver & Kidney & Liver & Kidney & Liver & Kidney \\
\hline Group I & $0.30 \pm 0.01^{\mathrm{a}}$ & $0.22 \pm 0.02^{\mathrm{a}}$ & $14.65 \pm 1.02^{\mathrm{a}}$ & $25.34 \pm 0.82^{\mathrm{a}}$ & $29.45 \pm 0.62^{\mathrm{a}}$ & $30.00 \pm 1.19^{\mathrm{a}}$ \\
\hline Group II & $0.12 \pm 0.04^{\mathrm{b}}$ & $0.12 \pm 0.03^{\mathrm{b}}$ & $7.75 \pm 1.79^{\mathrm{b}}$ & $13.40 \pm 2.11^{\mathrm{b}}$ & $15.75 \pm 3.17^{\mathrm{b}}$ & $16.74 \pm 4.31^{\mathrm{c}}$ \\
\hline Group III & $0.31 \pm 0.01^{\mathrm{a}}$ & $0.22 \pm 0.01^{\mathrm{a}}$ & $12.84 \pm 0.47^{\mathrm{a}}$ & $26.34 \pm 2.24^{\mathrm{a}}$ & $27.12 \pm 0.53^{\mathrm{a}}$ & $26.67 \pm 0.83^{\mathrm{ab}}$ \\
\hline Group IV & $0.28 \pm 0.01^{\mathrm{a}}$ & $0.18 \pm 0.02^{\mathrm{a}}$ & $11.58 \pm 1.62^{\mathrm{ab}}$ & $17.65 \pm 1.26^{\mathrm{b}}$ & $20.99 \pm 1.40^{\mathrm{b}}$ & $21.33 \pm 2.69^{\mathrm{bc}}$ \\
\hline
\end{tabular}

group (Group IV) when compared to sodium fluoride treated rats (Group II). There was a significant $(P<0.05)$ increase in GPx values of ameliorated group (Group IV) was observed when compared to NaF treated rats (Group II).

Significant decrease in PCV and Hb levels were observed in $\mathrm{NaF}$ treated group (II) when compared with the control group $[13,14]$. The decrease in haemoglobin concentration might be because of inhibition of globulin synthesis [15] or depression of erythropoiesis [16] or a decrease in the level of blood folic acid [17] or enhanced production of superoxide radicals and lipid peroxidation that lead to alterations in erythrocyte cell membrane function and structure [13]. Significant difference was noticed in between $\mathrm{NaF}$ and ameliorated groups which might be due to direct or indirect hematoprotective properties of aloe vera [18].

In the present study significant leucocytosis was observed in toxin treated group (Group II) when compared to the control. In ameliorated group (Group IV), non significant increase in TLC was noticed when compared to Group II rats which might be due to immunostimulatory activity of aloe vera [6].

In Differential leukocytes count, neutrophilia and lymphocytopaenia were observed in fluoride treated rats (Group II) when compared to the control rats. This significant decrease in mean lymphocyte count observed in toxin treated group (group II) $[14,19]$. Lymphocytopaenia might be due to depletion of lymphocytes in lymphoid organs like spleen and lymph nodes as observed in the present experimental study. In ameliorated group (Group IV), non significant increase in mean lymphocyte count was noticed when compared to Group II rats, which might be due to immunostimulatory activity of aloe vera [6].

Significant decrease in the serum total protein was noticed in $\mathrm{NaF}$ treated rats (Group II) when compared to the control rats (Group I) [20-22]. The decreased levels of serum protein might be due to reduced feed intake and increased protein catabolism or hepato-renal damage as observed microscopically. In ameliorated group (Group IV), non significant increase in serum protein levels was noticed when compared to the NaF treated rats (Group II) which might be due to cytoprotective effect of aloe vera over hepatocytes [23].

Significant increase in the serum creatinine was noticed in toxin treated rats (group II) when compared to the control rats (group I) [24]. The increased levels of creatinine in NaF fed groups might be due to functional renal damage as evidenced by microscopical examination of kidney or urinary excretion of fluoride [25]. In ameliorated group, non significant decrease in serum creatinine levels compared to toxin treated group was observed and it might be due to cytoprotective and antioxidant effects of aloe vera [26].

In the present study, there was a significant $(P<0.05)$ decrease in mean serum calcium levels in $\mathrm{NaF}$ treated rats (Group II) when compared to control rats (group I) [27]. This decrease in serum calcium might be due to the binding of calcium 
with fluoride to form calcium fluoride as evidenced by extensive histopathological changes in bones. In ameliorated group, non significant decrease in serum calcium levels compared to toxin treated group was observed and it might be due to antioxidant properties of aloe vera [6].

Alkaline Phosphatase (ALP) is the marker enzyme of fluoride toxicosis and bone pathology. An increase in serum alkaline phosphatase activity in animals treated with fluoride was observed in our study [28-30]. Increased activity of alkaline phosphatase might be due to the effect of fluorine intoxication on bone tissues or an increase in trabecular bone density which in turn might have lead to an increase in serum alkaline phosphatise [26] or binding of fluoride with magnesium ions, leading to inhibition of Mg-dependent enzymes, such as alkaline phosphatase [31]. In ameliorated group, non significant decrease in serum ALP levels compared to toxin treated group was observed and it might be due to cytoprotective and antioxidant effects of aloe vera [26].

In the present study a significant decrease in CAT, SOD and GPx was observed in liver and kidney of NaF treated animals when compared to control (Group I) [32-35]. The decrease in antioxidant enzymes activity in fluoride treated rats might be due to $\mathrm{NaF}$ induced generation of Reactive Oxygen Species (ROS) in liver and kidney. There was a significant $(P<0.05)$ increase in CAT, SOD and GPx values of ameliorated group (Group IV) when compared to $\mathrm{NaF}$ treated rats (Group II) were observed. This might be because of glycoprotein fraction of aloe vera that showed radical scavenging activity and isorabaichrome, an aloe derivative that has a potent antioxidant activity because of its caffeoyl group [36].

\section{Acknowledgements}

The authors are very much thankful to Sri Venkateswara Veterinary University, Tirupati for providing facilities to carry out Postgraduate research work in the Department of Veterinary Pathology, College of Veterinary Science, Tirupati.

\section{Rererences}

1. Nawlakhe WG, Paramasivam R. Defluoridation of potable water by Nalgonda technique. Curr Sci. 1993;65:10.

2. Chinoy N, Patel J. Effects of sodium fluoride and aluminium chloride on ovary and uterus of mice and their reversal by some antidotes. Fluoride. 2001;34:9-20.

3. Susheela A and Bhatnagar M. Reversal of fluoride induced cell injury through elimination of fluoride and consumption of diet rich in essential nutrients and antioxidants. Mol Cell Biochem. 2002;234235(1):335-340.

4. Nanda Kumar V, Singh T, Katiyar SK. Multi-targeted prevention and therapy of Cancer by proanthocyanidins. Cancer Lett. 2008;269(2):378-87. doi: 10.1016/j.canlet.2008.03.049.

5. Shukitt-Hale B, Lau F, Joseph J. Berry fruit supplementation and the aging brain. J Agric Food Chem. 2008;56(3):636-41. doi: 10.1021/ jf072505f.

6. Sharrif Moghaddasi M, Sandeep Kumar Verma. Aloe vera their chemicals composition and applications: A review. Int J Biol Med Res 2011;2(1):466-471.
7. Jain NC. Schalms Veterinary Hematology. $2^{\text {nd }}$ ed. Lea and Febiger: Philadelphia; 1986.

8. Coles EH. Veterinary Clinical Pathology. WB Saunders Company, Philadelphia: USA; 1986.

9. Marklund SL, Marklund G. Involvement of superoxide anion radical in the auto oxidation of pyrogallol and a convenient assay for superoxide dismutase. European Journal of Biochemistry. 1974;47:496-474.

10. Caliborne A L. Assay of catalase. In Handbook of Oxygen Radical Research. Ed. Greenward, R.A., CRC Press, Baco- Raton, 1985.

11. Rotruck JD, Pope AL, Ganther HE, Swanson AB, Hafeman DG and Hekstra, et al. Selenium, biochemical role as a component of glutathione peroxidase and assay. Science. 1973;179:588-590.

12. Snedecor WG, Cochran GW. Statistical Methods. $6^{\text {th }}$ ed. Oxford and IBH Publishing Company: New Delhi; 1994.

13. Bouaziz H, Hamadi Fetoui, Sabeur Ketata, Kamel Jammoussi, Feriel Ellouze, Najiba Zeghal. Effects of sodium fluoride ingested by lactating mice on some haematological parameters in suckling pups and dams. Fluoride. 2006; 39(3):211-219.

14. Karadeniz A, Altintas L. Effects of panax ginseng on fluoride-induced haematological pattern changes in mice. Fluoride. 2008;41(1):67-71.

15. Obrig T, Irvin J, Culp W. Inhibition of peptide initiation on reticulocyte ribosomes by edeine. Eur J Biochem 1971; 21:31-41.

16. Machalinski B, Zejmo M, Stecewicz I. The influence of sodium fluoride on the clonogenecity of human hematopoietic progenitor cells: preliminary report. Fluoride. 2000;33:168-173.

17. Hillman D, Bolenbaugh DL, Convey EM. Hypothyroidism and anemia related to fluoride in dairy cattle. J Dairy Sci 1979;62:416-423.

18. Egger SF, Brown GS, Kelsey LS, Yates KM, Rosenberg LJ, Talmadge JE. Hematopoietic augmentation by a beta $(1,4)$ linked mannan. USA Cancer Immunology and Immunotherapy 1996;43(4):195205.

19. Eren E, Ozturk M, Mumcu EF. Fluorosis and its hematological effects. Toxicol Ind Health. 2005;21:255-258.

20. Shashi A, Thapar SP and Singh JP. Effect of fluoride administration on organs of gastrointestinal tract: An experimental study on rabbits, effect on tissue protein. Fluoride. 1987;20:183-188.

21. Chinoy NJ, Sharma M and Michael M. Beneficial effects of ascorbic acid on reversal of fluoride toxicity in male rats. Fluoride. 1987;26:45-56.

22.Zang ZY, Fan JY, Yen W, Tian JY, Wong JG, Li XX, et al. The effect of nutrition on the development of endemic osteomalacia in patients with skeletal fluorosis. Fluoride. 1996;29:20-24.

23. Norikura T, Kennedy DO, Nyarko AK, Kojima A, Matsui Yuasa I. Protective effect of aloe extract against the cytotoxicity of 1,4naphthoquinone in isolated rat hepatocytes involves modulations in cellular thiol levels. Pharmacol Toxicol. 2002;90(5):27884.

24. Usuda K, Kono K, Dote T, Nishiura K, Miyata K, Nishiura H, et al. Urinary biomarkers monitoring for experimental fluoride nephrotoxicity. Arch. Toxicol. 1998;72:104-109.

25. Kono K, Yoshida Y, Yamagata H, Watanabe M, Shibuya Y, Doi K. Urinary fluoride monitoring of industrial hydrofluoric acid exposure. Environ Res. 1987;42:415-20.

26. Singh RP. Chemomodulatory action of aloe vera on the profiles of enzymes associated with carcinogen metabolism and antioxidant status regulation in mice. Phytomedicine. 2000; 7:209. 
27. Verma RJ, Guna Sherlin DM. Hypocalcaemia in parental and F1 generation rats treated with sodium fluoride. Food and Chemical Toxicol. 2002;40:551-554

28. Blood DC, Radostits OM, Henderson JA, Arundel JH, Gay CC. In Veterinary Medicine. $6^{\text {th }}$ ed. Bailliere Tindal and Cassel Ltd: London; 1983.

29. Farley JR, Wergedal JE, Baylink DJ. Fluoride directly stimulates proliferatin and alkaline phosphatase activity of bone forming cells. Science. 1983;222:330-332.

30. Teotia SPS and Teotia M. Endemic fluoride: bone and teeth update. Ind. J. Environ. Toxicol. 1991;(1):1

31. Haber P, Willvonseder R. Therapy of senile osteoporosis wing sodium fluoride continuous and intermittent long term therapy. Schweiz. Med. Wochenschr 1979;109(18):688-692.

32. Soni MG, Kachole MS and Pawar SS. Alteration in drug metabolising enzymes and lipid peroxidation in different rat tissues by fluoride. Toxicol. Lett. 1984;21:167-172.

33. Shanthakumari D, Seshachalam Srinivasalu and Sorimuthu Subramanian. Effect of fluoride intoxication on lipid peroxidation and antioxidant status in experimental rats. Toxicology. 2004;204:219228.

34. Akdogan M, Bilgili A, Karaoz E, Gokcimen A, Yarsan E and Eraslan G. The structural and biochemical alterations in liver tissue of rabbits receiving fluoride with water for a particular dose and period. Firat Univ. J. Health Sci. 2002;16: 41-46.

35. Inkielewicz I and Czarnowski W. Oxidative stress parameters in rats exposed to fluoride and aspirin. Fluoride. 2008;41(1):76-82.

36. Yagi A, Kabash A, Okamura N, Haraguchi H, Moustafa SM, Khalifa TI. Antioxidant, free radical scavenging and anti-inflammatory effects of aloesin derivatives in Aloe vera. Planta Med. 2002;68(11):95760. 